\title{
Molecular physicochemical parameters predicting antioxidant activity of Brazilian natural products
}

\author{
Luciana Scotti, ${ }^{1}$ Marcus Tullius Scotti, ${ }^{2}$ Kerly Fernanda Mesquita Pasqualoto, ${ }^{1}$ \\ Vanderlan da Silva Bolzani, ${ }^{3}$ Elizabeth Igne Ferreira ${ }^{1}$
}

\author{
${ }^{1}$ Department of Pharmacy, School of Pharmaceutical Sciences, University of São Paulo, \\ Av Prof. Lineu Prestes 580, Bl. 13, Conjunto das Químicas, Cidade Universitária, \\ 05508-900 São Paulo-SP, Brazil \\ ${ }^{2}$ Centro de Ciências Aplicadas e Educação, University Federal of Paraíba, Campus IV, Litoral Norte, \\ Rio Tinto-PB, Brazil \\ ${ }^{3}$ Institute of Chemistry, State University “Júlio de Mesquita Filho”, Rua Francisco Degni s/n, \\ 14800-900 Araraquara-SP, Brazil
}

\begin{abstract}
RESUMO: "Parâmetros físico-químicos na predição da atividade antioxidante de produtos naturais brasileiros". Espécies reativas de oxigênio (ROS) são capazes de oxidar proteínas celulares, ácidos nucléicos e lipídios; contribuindo para os processos de envelhecimento celular, mutações genéticas, doenças coronarianas, neoplásicas, degenerativas, dentre outras. Compostos fenólicos neutralizam a reatividade radicalar através da transferência de um elétron da sua estrutura molecular, seguida da abstração de um próton. Este trabalho avaliou a atividade antioxidante de dezessete compostos fenólicos, extraídos de duas plantas da flora nacional (Chimarrhis turbinata e Arrabidea samydoides). Através da modelagem molecular foram obtidos diversos parâmetros, como energias orbitalares, calor de formação das espécies neutras, radicalares e catiônicas, $\Delta \mathrm{H}_{\mathrm{ox}}$, $\Delta \mathrm{H}_{\mathrm{f}}$ e $\mathrm{Clog} \mathrm{P}$; que permitem predizer a atividade e indicar maior poder antioxidante nas moléculas 10 (a a f) para avaliação experimental.
\end{abstract}

Unitermos: Modelagem molecular, compostos fenólicos, atividade antioxidante.

\begin{abstract}
Reactive oxygen species (ROS) are capable of oxidizing cellular proteins, nucleic acids and lipids, contributing to cellular aging, mutagenesis, carcinogenesis, coronary heart and neurodegenerative diseases. Free radicals-scavenging by phenolic compounds occurs by the transfer of one electron followed by the $\mathrm{H}$-abstraction. In order to evaluate the antioxidant activity of a series of seventeen phenolic compounds extracted from Brazilian flora (Chimarrhis turbinata and Arrabidea samydoides), some physicochemical parameters (heat formation of the neutral, radical, and cationic compounds; orbitals' energies; $\mathrm{C} \log \mathrm{P} ; \Delta \mathrm{H}_{\mathrm{OX}}$; and $\Delta \mathrm{H}_{\mathrm{f}}$ ) were calculated. Considering the results from the calculated descriptors, the molecules 10a-f can be classified as having a higher antioxidant activity.
\end{abstract}

Keywords: Molecular modeling, phenolic compounds, antioxidant activity.

\section{INTRODUCTION}

Reactive oxygen species (ROS) are capable of oxidizing cellular proteins, nucleic acids and lipids. Lipid peroxidation is a free radical mediated propagation of oxidative injure to polyunsaturated fatty acids involving several types of free radicals (Thomas, 2000). The chain reaction interruption occurs through enzymatic means or free radical scavenging by antioxidants. ROS contribute to the acceleration of cellular aging, mutagenesis, carcinogenesis, and coronary heart disease, possibly through a mechanism of destabilization of membranes, DNA damage, and oxidation of LDL. Antioxidants protect these targets against the effects of free radicals and they can be enzymatic or non-enzymatic agents, histidinepeptides and iron-binding proteins. Phenolic antioxidants such as vitamin E, hydroxytyrosol, gallic acid, caffeic acid, chicoric acid, flavonoids and epicatechin are extremely important. The radical-scavenging potentials of these compounds have been extensively investigated, but the exact molecular mechanisms radical-quenching reaction has not been explored enough (Lien et al., 1999; Del Rio et al., 2002).

In this work, one of the species selected was Chimarrhis turbinata DC., Rubiaceae, a plant is widely spread from Central America and the Caribbean throughout 
the tropical South America, mostly concentrated in the Amazon region and has the popular name "pau-de-remo". Rubiaceae species are well known for their biological activities and medicinal uses, bearing metabolites such as flavonoids and indole alkaloids, both chemotypes known for having potential biological activities (Cardoso et al., 2005). Arrabidaea samydoides (Cham.) Sandwith, Bignoniaceae, was also studied The Bignoniaceae family comprehend about 120 genera and 800 species distributed throughout tropical regions of South America and Africa. Species from the genus Arrabidaea DC. have been used for wound asepsis and treating intestinal disorders (Pauletti et al., 2003a,b).

Molecular modeling is a computational tool based on the methods of theoretical chemistry and experimental data, construction and manipulation of chemical or biological models. The calculations involve physicochemical parameters. Such properties as heat of formation, enthalpies, activation energies, hydrophobic character, among others, might be derived from methods including semi-empirical and the information about steric, electronic and lipophilicity nature of the compounds. It assists the understanding of the mechanism of action responsible for the biological effect (Cohen, 1996; Leach, 2001).

The mechanism of antioxidant activity depends on two factors: the eletron-proton transfer and the stability of the formed free radical. Phenolic antioxidants (Ar-OH) need to react faster than biomolecules with free radicals to protect the latter from oxidation. The hydrogen atom $(\mathrm{H})$ of Ar-OH is transferred as a proton $(\mathrm{H}+)$ and an electron to the radical oxygen ( $\left.\mathrm{ROO}^{\circ}\right)$ using different sets of orbital.
Thus, one electron is transferred from the phenol oxygen (Ar-O-H) to the radical oxygen (RO-O*) and then the proton is moved as a $\mathrm{H}^{+}$ion (Leopoldini et al., 2004).

$\mathrm{Ar}-\mathrm{OH}+\mathrm{RO}_{2} \longrightarrow\left[\mathrm{Ar}^{-} \mathrm{OH}^{\delta^{+}} \mathrm{RO}_{2}^{\delta^{-}}\right] \longrightarrow\left[\mathrm{Ar}-0^{\bullet} \mathrm{RO}_{2} \mathrm{H}\right] \longrightarrow \mathrm{Ar}-\mathrm{O}^{\bullet}+\mathrm{RO}_{2} \mathrm{H}$

In the industry is not feasible to experimentally test the millions of chemicals in industry combinatorial databases and Computer-aided Drug Design, including Molecular Modeling, which can provide a screening alternative. Theoretical methods can be used with advantages in several studies, not only in the research of new substances, but they might be used to investigate toxicity, potency, stability and functionalities of known compounds (Cao et al., 2005).

\section{MATERIAL AND METHODS}

\section{Material}

Seventeen phenolic compounds, endowed with potential antioxidant activity and originated from Brazilian flora extracts, was evaluated: eleven phenolic compounds from Chimarrhis turbinata DC., Rubiaceae, (Chimarrhis class) (1a-9) (Cardoso et al., 2005), and six phenolic compound from Arrabidaea samydoides (Cham.) Sandwith, Bignoniaceae, (Arrabidaea class) (10a-10f) (Pauletti et al., 2003b). In this theoretical study, physicochemical parameters were computed to evaluate the quenching of free radicals by phenolic compounds obtained from these Brazilian species.<smiles>[R]c1cc(-c2oc3cc(O)c([R2])c(O)c3c(=O)c2OC)ccc1O</smiles>

$1 \mathrm{a} \mathrm{R}_{1}=\mathrm{OH} ; \mathrm{R}_{2}=\mathrm{H}$ 1 b $\mathrm{R}_{1}=\mathrm{R}_{2}=\mathrm{OH}$ $1 c R_{1}=H ; R_{2}=O H$<smiles>C[C@@]1(c2c(O)cc(O)c3c2OC(c2ccc(O)c(O)c2)C(O)C3)c2c(O)cc(O)cc2OC(c2ccc(O)c(O)c2)[C@H]1O</smiles><smiles></smiles><smiles>COc1c(-c2ccc(O)cc2)oc2cc(C)cc(O)c2c1=O</smiles><smiles>O=C(/C=C/c1ccc(O)c(O)c1)OC1CCC(O)C1O</smiles><smiles>COC(=O)C1(O)CC(O)C(O)[C@@H](OC(=O)CCc2ccc(O)c(O)c2)C1</smiles><smiles>COC(=O)C1(O)CC(O)C(O)[C@H](OC(=O)/C=C/c2ccc(O)c(O)c2)C1</smiles>

7

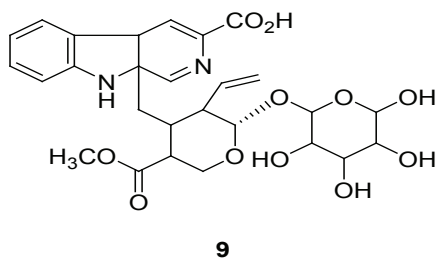


<smiles>CC(=O)/C=C/c1ccc(O)cc1</smiles>

a<smiles>CC(=O)c1ccc(O)cc1</smiles><smiles>CC(=O)/C=C/c1cc(O)cc(O)c1</smiles>

b<smiles>CC(=O)c1ccccc1</smiles>

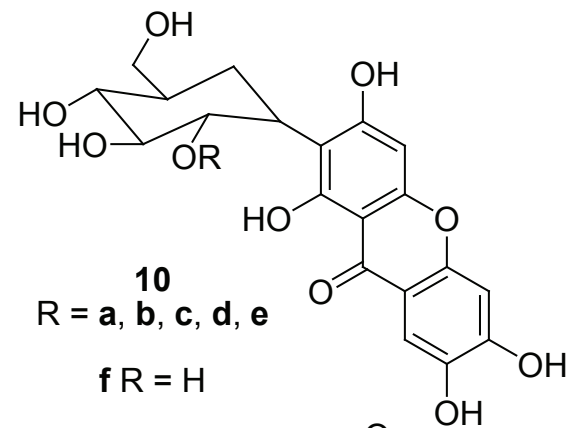<smiles>CC(=O)/C=C/c1ccccc1</smiles>

e

\section{Methods}

The program Spartan for Windows v 4.0 was used in a microcomputer with Pentium 4 processor. The compounds were drawn and the geometries were optimized using the field of force of molecular mechanics MMFF (Harihan \& Pople, 1973). A new optimization of the geometry was adopted using the semi-empiric method AM1 (Austin Model 1) (Dewar et al., 1985). The choice of the AM1 method was based on the satisfactory results presented on the planning and evaluation for the molecular modeling of antioxidant substances (Cheng et al., 2002; Vasilescu \& Girma, 2002). The options selected in the procedure of the geometry optimization, like multiplicity and total charge, were the following: charge 0 and singlet for the closed shell species (fn); charge 0 and doublet for the free radicals (fr); charge 1 and doublet for the cationic species (fc) (Scotti et al., 2005).

The optimized structures of the closed shell species were submitted to the conformational analysis, randomic method by Monte Carlo. The conformer of minimum energy was selected and used to built the species radical (for abstraction of the phenolic hydrogen) and the species cation-radical (for addition the proton $\mathrm{H}^{+}$) by the analysis of the parameters to continue the second electronic determination of charge of single point. In the chemical structure of conformer of minimum energy, the differences of enthalpies of all hydroxyl groups were calculated. The smallest difference represents that larger capacity to donate the electron, thus, the parameters were calculated in this phenolic radical.

The parameters employed to the anti-radicalar activity description were:

- $\Delta \mathrm{H}_{\mathrm{f}}$, difference of enthalpy energy between the closed shell (phenolic) and radical (abstraction of the hydrogen) species;
- $\Delta \mathrm{H}_{\mathrm{OX}}$, energy activation of the intermediate cation radical, calculated by the difference between $\mathrm{Hf}$ fc and Hf fn, and also defined as the electron transfer enthalpy;

- $\mathrm{E}_{\mathrm{HOMO}}$, energy of the highest occupied molecular orbital, a parameter related to the electron-donating capacity of the molecule;

- $\mathrm{E}_{\text {LUMO }}$, energy of lowest orbital molecular, a parameter related to the electron-donating capacity of the molecule;

- H-Lgap, chemical hardness obtained by the difference of energy between orbital HOMO and LUMO;

- ClogP, parameter that estimates the hydrophobic interactions using Ghose-Pritchett-Crippen theoretical method (Ghose et al., 1988).

\section{RESULTS AND DISCUSSION}

The physical-chemical properties as well as the biological activity of organic compounds depend on their molecular structures. Only the most stable conformation of antioxidants and their corresponding phenoxyl free radical were taken into consideration when discussing the possible hydroxyl radical scavenging mechanisms. The results obtained in this theoretical study are shown on Tables 1 and 2 .

Among the calculated parameters, $\Delta \mathrm{Hf}$ value is the difference of heat formation between phenolic neutrals and its radicals considered after $\mathrm{H}$-abstraction reaction (Zhang, 1999; Vaya et al., 2003). QSAR (Quantitative Structure-Activity Relationships) studies from literature report that when $\Delta \mathrm{Hf}$ increases the transfer of hydrogen from the parent compounds is unfavorable, rendering the phenolic compounds poorer antioxidants (Cheng et al., 2002; Weber et al., 2006; Scotti et al., 2005).

The molecules 1c, 2, 4, 8 and 10 (a-f), showed 
smaller values of the parameter $\Delta \mathrm{Hf}$, suggesting hydroxyls groups with capacity to free radical-scavenger through the donation of an electron. The antioxidant action can also involve a single electron transfer $\left(\mathrm{E}_{\text {номо }}\right)$. The energy level of the highest occupied molecular orbital $\left(\mathrm{E}_{\text {номо }}\right)$ is a parameter reflecting the electron-donation ability, which also inferred an electron transfer process involved in the $\mathrm{H}$-abstraction reaction. Antioxidant activity of the compound must present favorable electronic characteristics. It is important to observe the $\mathrm{H}-\mathrm{L}_{\text {gap }}$ in compounds with smaller values of $\Delta \mathrm{Hf}$ because it reflects their reactivity. Those with larger $\mathrm{H}-\mathrm{L}_{\text {gap }}$ are less active than those with a smaller $\mathrm{H}-\mathrm{L}_{\text {gap }}$.

Regarding $\Delta \mathrm{H}_{\mathrm{OX}}$, it was shown that it decreases with the increase of radical-scavenging activity. The value of $\mathrm{C} \log \mathrm{P}$ is related to a greater or smaller similarity of the compound to the cellular structures. The molecule 9 presented the smallest value among the studied compounds, 1-10. The heteroatom nitrogen, the elevate number of hydroxyls in the sugar and the presence of double bonds contributed to the increase of the polarity of the molecule. In this study, $C \log \mathrm{P}$ parameter does not show significant difference among molecules $\mathbf{1 a}, \mathbf{1 b}$ and $\mathbf{1 c}$. This can be attributed to the method of Ghose-Pritchett-Crippen to calculate the $\mathrm{C} \log \mathrm{P}$, which uses molecular fragments, that cannot distinguish compounds 1a and 1c, for example. This parameter, available in the Spartan program, was calculated additionally to the electronic ones that showed larger weight in a previously QSAR study. In 3 , the removal of the double bonding between $\mathrm{C} 2-\mathrm{C} 3$ of $\mathbf{1 a}, \mathbf{1 b}$ and $\mathbf{1 c}$ had also contributed for an increase of lipophilicity. Other molecules showed polarity variations according to the characteristics evaluated, such as the number of hydroxyls, presence of double bonds and sugar and ring heterocycle.

Thus, the molecules 10 (a-f), 1 (a-c), 4, 6, 7, 8 may have a good antioxidant activity. We considered that the molecules $10(\mathbf{a}-\mathbf{f})$ presents greater favorable values from all parameters.

Table 1.Computed theoretical parameters by Spartan for Windows v. 4.0 software of Chimarrhis turbinata.

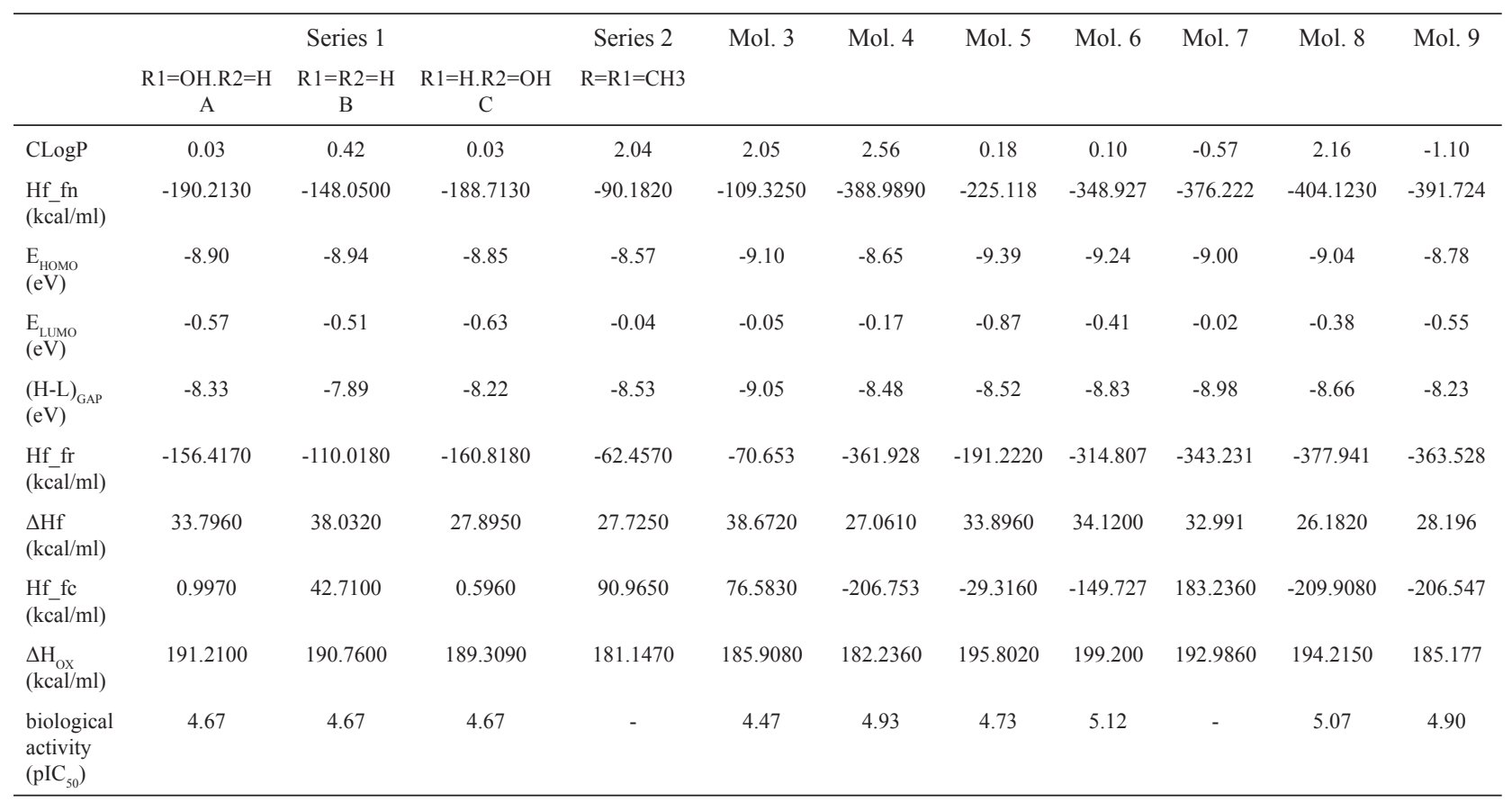

$\mathrm{IC}_{50}$ - biological activity ( $\left.\mu \mathrm{mol}\right)$, ClogP- calculated lipophilicity; Hf_fn, Hf_fc, Hf_fr- heat of formation of the phenolic, cationic and radical species; $\mathrm{E}_{\text {номо }}$-energy of Highest Occupied Molecular Orbital; $\mathrm{E}_{\mathrm{Lumo}}$-energy of Lowest Unoccupied Molecular Orbital; $\Delta$ Hf-difference of of heat of formation of the phenolic and radical species; $\Delta \mathrm{H}_{\mathrm{ox}}$-difference of of heat of formation of the phenolic and cationic species. 
Table 2. Computed theoretical parameters by Spartan for Windows v. 4.0 software of Arrabidaea samydoides.

\begin{tabular}{|c|c|c|c|c|c|c|}
\hline Mol. 10 & a & $\underset{b}{\mathrm{OH}}$ & 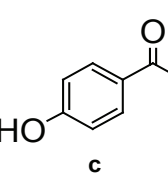 & 시 & e & H- \\
\hline CLogP & 1.91 & 2.29 & 2.45 & 2.49 & 1.52 & 4.16 \\
\hline Hf_fn (kcal/ml) & -424.9340 & -466.9380 & -445.6440 & -401.921 & -381.2730 & -405.3600 \\
\hline $\mathrm{E}_{\text {номо }}(\mathrm{eV})$ & -9.13 & -8.85 & -9.14 & -9.30 & -9.12 & -9.18 \\
\hline $\mathrm{E}_{\text {LUMO }}(\mathrm{eV})$ & -0.88 & -1.02 & -0.89 & -1.06 & -0.87 & -0.94 \\
\hline$(\mathrm{H}-\mathrm{L})_{\mathrm{GAP}}(\mathrm{eV})$ & -8.25 & -7.83 & -8.25 & -8.24 & -8.25 & -8.24 \\
\hline Hf_fr (kcal/ml) & -395.2200 & -439.1460 & -422.2250 & -372.9980 & -352.5530 & -376.6560 \\
\hline$\Delta \mathrm{Hf}(\mathrm{kcal} / \mathrm{ml})$ & 29.7140 & 27.7920 & 23.41790 & 28.92300 & 28.7200 & 28.7040 \\
\hline Hf_fc $(\mathrm{kcal} / \mathrm{ml})$ & -230.1600 & -272.7150 & -257.36790 & -202.4390 & -186.8670 & -209.3460 \\
\hline$\Delta \mathrm{H}_{\mathrm{OX}}(\mathrm{kcal} / \mathrm{ml})$ & 194.7740 & 194.2230 & 188.2750 & 199.4820 & 194.4060 & 196.0140 \\
\hline $\begin{array}{c}\text { biological } \\
\text { activity }\left(\mathrm{pIC}_{50}\right)\end{array}$ & 4.59 & 4.74 & 4.51 & 4.48 & 4.50 & 4.46 \\
\hline
\end{tabular}

$\mathrm{IC}_{50}$ - biological activity $(\Delta \mu \mathrm{mol})$, ClogP- calculated lipophilicity; Hf_fn, Hf_fc, Hf_fr- heat of formation of the phenolic, cationic and radical species; $\mathrm{E}_{\text {номо }}$-energy of Highest Occupied Molecular Orbital; $\mathrm{E}_{\text {Luмо }}$-energy of Lowest Unoccupied Molecular Orbital; $\Delta$ Hf-difference of of heat of formation of the phenolic and radical species; $\Delta \mathrm{H}_{\mathrm{ox}}$-difference of of heat of formation of the phenolic and cationic species.

\section{CONCLUSIONS}

Based on the interdependence of physicochemical variables and their correlation to antioxidant activity, it was reasonable to conclude that multiple mechanisms regulate the antioxidant actions of phenolic compounds in a significant way although their contribution to the antioxidant activity occurs at different degrees.

The techniques of computer-aided drug design, such as the molecular modeling, are just a tool as a filter before experimental studies. Thus, the molecules 10a to 10f showed good antioxidant activity, but they need other theoretical calculations, like based on the density functional theory (DFT) to help understand the antioxidant activity of the molecular structure of the compounds (Cao et al., 2005).

\section{ACNOWLEDGEMENTS}

The authors acknowledge the financial support given by FAPESP, CAPES and $\mathrm{CNPq}$ (Brazilian agencies)

\section{REFERENCES}

Cao H, Cheng W-X, Li C, Pan X-L, Xie X-G, Li T-H 2005. DFT study on the antioxidant activity of rosmarinic acid. $J$ Mol Struct 719: 177-183.

Cardoso CL, Silva DHS, Castro-Gamboa I, Bolzani VS 2005. New biflavonoid and other flavonoids from the leaves of
Chimarrhis turbinata and their antioxidant activities. $J$ Braz Chem Soc 16: 1353-1359.

Cheng Z, Ren J, Li Y, Chang W, Chen Z 2002. Study on the multiple mechanisms underlying the reaction between hydroxyl radical and phenolic compounds by qualitative structure and activity relationship. Bioorg Med Chem 10: 4067-4073.

Cohen NC 1996. Guidebook on molecular modeling in drug design. San Diego: Academic Press.

Del Rio LA, Corpas FJ, Sandalio LM, Palma JM, Gomez M, Barroso JB 2002. Reactive oxygen species, antioxidant systems and nitric oxide in peroxisomes. $J$ Exp Bot 53: 1255-1272.

Dewar MJS, Zoebisch EG, Healy EF, Stewart JJP 1985. AM1: A new general purpose quantum mechanical molecular model. J Am Chem Soc 107: 3902-3909.

GhoseAK,PritchettA, Crippen GM1988.Atomicphysicochemical parameters for three dimensional structure directed quantitative structure-activity relationships III: Modeling hydrophobic interactions. J Comp Chem 9: 80-90.

Hariharan PC, Pople JA 1973. The influence of polarization functions on molecular orbital hydrogenation energies. Theoret Chim Acta 28: 213-222.

Leach AR 2001. Molecular Modeling: Principles and Applications, England: Prentice Hall.

Leopoldini M, Marino T, Russo N, Toscano M 2004. Antioxidant properties of phenolic compounds: H-Atom versus electron transfer mechanism. J Phys Chem A 108: 49164922.

Lien EJ, Ren S, Bui HH, Wang R 1999. Quantitative structureactivity relationship analysis of phenolic antioxidants. Free Radical Biol Med 26: 285-294. 
Pauletti PM, Bolzani VS, Yong, MCM 2003a. Constituintes químicos de Arrabidaea samydoides (Bignoniaceae). Quim Nova 26: 641-643.

Pauletti PM, Castro-Gamboa I, Silva DHS, Young MCM, Tomazela DM, Eberlin MN, Bolzani VS 2003b. New antioxidant C-Glucosylxanthones from the stems of Arrabidaea samydoides. J Nat Prod 66: 1384-1387.

Scotti L, Scotti MT, Cardoso, CL, Pauletti PM, Castro-Gamboa I, Bolzani VS, Velasco MVR, Menezes CMS, Ferreira EI 2005. Avaliação quali- e quantitativa da relação entre estrutura química e atividade antioxidante de compostos da flora brasileira. In: Reunião Anual da Sociedade Brasileira de Química, 28. Poços de Caldas. Livro de resumos. São Paulo: SBQ. res.MD28.

Thomas MJ 2000. The role of free radicals and antioxidants, Nutrition 16: 716-718.

Vasilescu D, Girma R 2002. Quantum molecular modeling of quercetin-simulation of the interaction with the free radical $t$-BuOO. Int J Quantum Chem 90: 888-902.

Vaya J, Mahmood S, Goldblum A, Aviram M, Volkova N, Shaalan A, Musa R, Tamir S, 2003. Inhibition of LDL oxidation by flavonoids in relation to their structure and calculated enthalpy. Phytochemistry 62: 89-99.

Weber KC, Honório KM, Bruni AT, Andricopulo AD, Silva ABF 2006. A partial least squares regression study with antioxidant flavonoid compounds. Struct Chem17: 307313.

Zhang Y 1999. Theoretical methods used in elucidating activity differences of phenolic antioxidants, $\mathrm{J} \mathrm{Am} \mathrm{Oil} \mathrm{Chem} \mathrm{Soc}$ 76: 745-748. 